\title{
MEMBANDINGKAN ISTILAH ARSITEKTUR TRADISIONAL VERSUS ARSITEKTUR VERNAKULAR: STUDI KASUS BANGUNAN MINANGKABAU DAN BANGUNAN BALI
}

\author{
Gatot Suharjanto \\ Architecture Department, Faculty of Engineering, Binus University \\ Jl. K.H. Syahdan No. 9, Palmerah, Jakarta Barat 11480 \\ gatotsuharjanto@binus.edu
}

\begin{abstract}
The term 'vernacular' and 'traditional' in architecture context actually has a root meaning which is almost the same; both have the same meaning that can be attached to one form of architecture work which is oriented on locality aspects and historiy of its existence. However, how can we distinguish the two terms? One way to find it out is to do a case study on two traditional architecture buildings: Balinese buildings and Minangkabau buildings taken as the sample study. In general, both building have two criteria: culture philosophy and adaptative modernism. Through descriptive analytical methods, the two building types were analyzed to acquire the definition of the building shapes which can be classified whether they belong to vernacular or traditional. The results show that vernacular architecture is a form of original work which is specified with the content and a very strong local and contextual philosophy proper to its time, while the traditional architectural building is a vernacular masterpiece recognized by acclamation and hereditary within a very long time.
\end{abstract}

Keywords: traditional architecture, vernacular architecture, Balinese building, Minangkabau building

\begin{abstract}
ABSTRAK
Istilah vernakular dan tradisional dalam konteks arsitektur sebetulnya memiliki akar makna yang hampir sama; keduanya memiliki makna yang sama-sama dapat dilekatkan pada salah satu bentuk karya arsitektur yang berorientasi pada aspek lokalitas dan sejarah rentang waktu keberadaannya. Namun, sejauh apa perbedaan kedua istilah ini bisa dimengerti? Salah satu cara untuk mengetahuinya adalah melakukan pendekatan studi kasus terhadap dua bentuk karya arsitektur tradisional, yaitu bangunan Bali dan bangunan Minangkabau yang diambil sebagai sampel penelitian. Secara umum keduanya memiliki dua kriteria, yaitu kriteria filosofis budaya dan adaptatif modernis. Melalui metode deskriptif analitis, dua jenis bangunan ini dianalisis untuk memperoleh makna bentuk karya bangunan yang bisa digolongkan apakah termasuk vernakular ataukah tradisional. Hasil penelitian menunjukkan bahwa arsitektur vernakular adalah bentuk karya orisinal yang sangat spesifik dengan kandungan dan filosofi lokal yang sangat kuat dan bersifat kontekstual sesuai dengan zamannya, sementara bangunan arsitektur tradisional adalah maha karya vernakular yang diakui secara aklamasi dan turun temurun dalam rentang waktu yang lama dan bahkan sangat lama.
\end{abstract}

Kata kunci: Arsitektur, Tradisional, Vernakular, bangunan Minangkabau, bangunan Bali 


\section{PENDAHULUAN}

Istilah arsitektur tradisional dan arsitektur vernakular sangat sering digunakan dalam ranah arsitektur. Kedua istilah ini acap kali muncul ketika dikaitkan dengan konsep dan desain yang bersentuhan dengan aspek budaya, genius lokal, dengan rentang waktu (lifetime) dan sebagainya.

Meski keduanya memiliki akar makna yang tidak jauh berbeda, ada hal hal prinsip yang dapat diungkapkan agar jelas terlihat perbedaannya sehingga lebih mudah untuk dipahami dengan mengedepankan contoh perbedaan dalam bentuk studi kasus.

\section{Tradisional - Tradisi - Arsitektur Tradisional}

Kata tradisi berasal dari bahasa Latin traditionem, dari traditio yang berarti "serah terima, memberikan, estafet", dan digunakan dalam berbagai cara berupa kepercayaan atau kebiasaan yang diajarkan atau ditularkan dari satu generasi ke generasi berikutnya, biasanya disampaikan secara lisan dan turun temurun. Sebagai contoh adalah tradisi kegiatan masyarakat di Indonesia saat perayaan peringatan hari kemerdekaan RI di setiap tanggal 17 Agustus. Masyarakat Indonesia kerap menyelenggarakan perlombaan-perlombaan, tumpengan dan berbagai kegiatan unik lainnya. Kegiatan semacam ini tidak diketahui kapan dimulainya dan siapa yang memulainya. Namun demikian, kegiatan ini telah berlangsung sekian lama secara berulang-ulang sehingga masyarakat menjadikan kegiatan tersebut perlu dan harus dilakukan. Inilah yang bisa disebut sebagai tradisi. Demikian pula kegiatan-kegiatan yang mengatasnamakan aktivitas-aktivitas keagamaan.

Tradisi adalah sebuah praktek, kebiasaan, atau cerita yang dihafalkan dan diwariskan dari generasi ke generasi, awalnya tanpa memerlukan sebuah sistem tulisan. Tradisi sering dianggap menjadi kuno; dianggap sangat penting untuk dijaga. Namun demikian ada juga beberapa tradisi yang memang sengaja diciptakan demi mencapai tujuan-tujuan tertentu; sebagai alat untuk memperkuat kepentingan atas kalangan tertentu dan lain sebagainya. Tradisi semacam itu ternyata dapat diubah sesuai dengan kebutuhan saat itu dan perubahan itu masih bisa diterima sebagai bagian dari tradisi kuno. Sebagai contoh yang termasuk "penemuan tradisi" di Indonesia adalah pada masa pendudukan kolonial Belanda, mereka membutuhkan pengakuan kekuasaan di wilayah mereka berada sehingga usaha terbaik yang harus mereka lakukan adalah dengan menciptakan sebuah "tradisi" yang bisa mereka gunakan sebagai alat untuk melegitimasikan posisi mereka sendiri. Dalam hal ini mereka memanfaatkan keberadaan seorang raja sebagai alat untuk mempersatukan rakyat dibawahnya agar tetap loyal dan hormat pada sang raja sehingga mudah dikendalikan oleh sang raja dan tentu saja oleh pendudukan kolonial yang menguasai sang raja. Dengan demikian kekuasaan kolonial secara tidak langsung akan menyerap ke dalam tradisi rakyat setempat.

Dalam tataran teoritis, tradisi dapat dipandang sebagai informasi atau terdiri atas informasi. Informasi yang dibawa dari masa lalu ke masa kini dan dalam konteks sosial tertentu. Sehingga informasi ini bisa dianggap sebagai bagian yang paling mendasar meski secara fisik ada tindakantindakan atau aktifitas tertentu yang secara terus menerus juga dilakukan pengulangan-pengulangan sepanjang waktu. Dengan demikian Tradisi adalah sebuah kegiatan yang dilakukan secara terus menerus atau sebuah kebudayaan atau sebuah hasil karya yang dianggap berhasil dan memiliki legitimasi dalam kurun waktu yang cukup panjang dan bahkan sangat panjang (lama) yang diikuti oleh generasi generasi berikutnya secara turun temurun.

\section{Vernakular - Arsitektur Vernakular}

Menurut Yulianto Sumalyo (1993), vernacular adalah bahasa setempat, dalam arsitektur istilah ini untuk menyebut bentuk-bentuk yang menerapkan unsur-unsur budaya, lingkungan termasuk iklim 
setempat, diungkapkan dalam bentuk fisik arsitektural (tata letak denah, struktur, detail-detail bagian, ornamen, dll).

Sementara definisi arsitektur vernakular menurut Paul Oliver dalam Encyclopedia of Vernacular Architecture of the World adalah terdiri dari rumah-rumah rakyat dan bangunan lain, yang terkait dengan konteks lingkungan mereka dan sumber daya tersedia yang dimiliki atau dibangun, menggunakan teknologi tradisional. Semua bentuk arsitektur vernakular dibangun untuk memenuhi kebutuhan spesifik untuk mengakomodasi nilai-nilai, ekonomi dan cara hidup budaya yang berkembang. berikut ini.

Sebuah cerita menarik tentang perkembangan arsitektur vernacular ditulis oleh Salura (2008)

Adalah Bernard Rudofsky (1910 - 1987) seorang pionir yang kemudian mencuatkan kemunculan vernakular. Ia bukanlah seorang yang memiliki latar belakang akademis; hanya seorang arsitek sekaligus seorang pengamat seni yang dengan kemampuannya berhasil merilis sebuah buku tentang "pakaian” yang berjudul Apakah Pakaian Kita Modern? Buku yang berjudul asli "Are our Clothes Modern?" ini cukup menarik untuk disimak yang menceritakan bahwa hampir semua kisah sejarah yang ditemuinya memaparkan "pakaian” para raja-raja beserta lingkup kerajaannya serta pemuka agama. Hal inilah yang kemudian mendorongnya untuk mengumpulkan dan menyajikan catatan maupun sketsa budaya pakaian masyarakat biasa dari berbagai penjuru negeri. Catatan inilah yang kemudian menarik perhatian banyak kalangan termasuk penyandang dana kelas dunia untuk mensponsori penelitian-penelitian berikutnya. Termasuk juga kajian tentang arsitektur, yang tentunya tetap mengusung sesuatu kebudayaan yang berasal dari masyarakat biasa - masyarakat yang memiliki keunikan arsitektur tanpa diketahui siapa sang arsiteknya. Rudofsky menyebut karya penelitian ini dengan istilah non formal architecture.

Hingga akhirnya dari hasil penelitiannya tersebut pada tahun 1964, ia pamerkan di sebuah museum seni modern di New York bersamaan dengan peluncuran bukunya yang berjudul "Arsitektur Tanpa Arsitek". Sesuai judulnya buku ini memaparkan tentang pemukiman dan rumah-rumah masyarakat biasa, yang jelas sangat berseberangan dengan kajian yang banyak muncul disaat yang sama dimana fokus yang dipaparkan rata-rata lebih didominasi pada bangunan istana, kerajaan ataupun bangunan keagamaan. Dari buku yang berjudul asli "Architecture Without Architects” ini membuat banyak kalangan menjadi sadar bahwa pandangan sempit selama ini tentang seni bangunan yang cenderung pada obyek kemegahan dan keagungan raksasa kerajaan tersebut harus segera di sejajarkan dengan sebuah karya hasil kejeniusan lokal masyarakat biasa.

Demikianlah sejak Rudofsky menggelar pameran bertajuk sama dengan bukunya yaitu "Architecture Without Architects" ia kemudian menyebut jenis arsitektur ini dengan sebutan "vernacular-architecture". Jika dirujuk kedalam kamus-kamus bahasa, Istilah vernakular ternyata merujuk kedalam ilmu bahasa (linguistik) yang secara harfiah berarti logat, dialek atau bahasa asli setempat, sehingga tepat rasanya jika label vernakular ini oleh nya ditempelkan pada jenis bangunanbangunan rakyat yang menunjukkan kadar kekentalan lokalitas setempat. Sejak itu pula muncul para teoritisi yang memposisikan dirinya sebagai pengamat atau pengkaji baru dalam teori arsitektur vernakular ini. Salah satunya yang paling dijadikan rujukan oleh para pengkaji vernakular adalah Amos Rapoport. Berdasarkan tradisi cara membangunnya, Rapoport dalam buku klasiknya House Form and Culture, membagi bangunan menjadi grand-tradition (tradisi megah) dan folk-tradition (tradisi rakyat). Kemegahan Istana dan bangunan keagamaan digolongkan ke dalam grand-tradition. Sementara architecture without architects digolongkan sebagai bangunan folk-tradition. Pada klasifikasi folk-tradition ia menempatkan dua kelompok: arsitektur primitif dan arsitektur vernakular. Rapoport kemudian mengidentifikasi lebih lanjut bahwa jenis arsitektur vernakular yang ada dapat dipisahkan sebagai vernakular-tradisional dan vernakular-modern. 


\section{METODE}

Untuk mendapatkan gambaran aspek perbedaan yang cukup jelas antra istilah arsitektur vernakular dan arsitektur tradisional, salah satu cara yang bisa digunakan adalah dengan melakukan pendekatan studi kasus terhadap dua bentuk karya arsitektur tradisional yang ada di Indonesia, yaitu bangunan Bali dan bangunan Minangkabau. Melalui metode deskriptif analitis, kedua bangunan yang benar-benar berakar filosofis budaya, dan berdiri atas budaya adaptatif modernis dianalisis untuk kemudian diperoleh makna bentuknya; apakah karya tersebut termasuk vernakular ataukah tradisional.

\section{PEMBAHASAN}

Hampir setiap bangunan dalam kurun waktu tertentu akan mengalami perubahan baik langsung maupun tidak langsung, berubah akibat adanya proses adaptasi untuk menghadapi perubahan kebutuhan di tiap-tiap generasi ataupun karena faktor alam. Perubahan ini terjadi karena adanya perubahan peradaban, perubahan spirit zaman dan perubahan dari era lama ke era baru, misalnya dari era pertanian ke era industri, sehingga kemapanan secara ekonomis tentu berubah dan pada akhirnya berujung pada sebuah kebutuhan perubahan yang berimbas pada bangunan.

Seperti yang diungkap Bernard Rudofdky bahwa arsitektur vernakular dibuat oleh orang-orang biasa, sehingga muncullah pertanyaan: dari mana kemampuan membangun itu berasal sehingga dihasilkan bangunan-bangunan yang bagus, indah, teratur, cocok dengan kebutuhan, hemat energi dan berbagai keunggulan lain?

Untuk menjawab pertanyaan itu perlulah diketahui terlebih dahulu mekanisme yang bekerja dalam masyarakatnya. Karena arsitektur vernakular adalah arsitektur milik bersama dalam sebuat tatanan masyarakat baik individu maupun kelompok. Ada konsistensi aturan, bentuk, penggunaan bahan, ornamen, dimensi dan sebagainya yang tentunya membutuhkan kesepakatan dalam masyarakat pendukungnya. Perlu dipahami berbagai jenis masyarakat dan bagaimana mereka mengatur tugastugas para anggotannya.

Mekanisme estafet penerusan pengetahuan bangun-membangun ini mengandalkan hubunganhubungan yang sudah ada antar anggota masyarakatnya; dari orang tua ke anaknya, dari orang yang sudah berpengalaman kepada orang yang masih belajar. Mekanisme inilah yang disebut sebagai tradisi.

Mempelajari dan memahami arsitektur vernakular dengan demikian tidak hanya mempelajari bentuknya, tapi juga mengenali bagaimana bentuk-bentuk itu terlahir. Kekuatan atau tradisi apa saja dalam masyarakatnya yang telah melahirkannya dan dengan cara bagaimana kekuatan atau tradisi itu terwujudkan.

Meminjam istilah Christopher Alexander bahwa arsitektur itu mempunyai bahasa, maka bahasa arsitektur vernakular erat sekali hubungannya dengan aspek-aspek tradisi. Tradisi memberikan suatu jaminan untuk melanjutkan kesinambungan tatanan sebuah arsitektur melalui sistem persepsi ruang yang tercipta, bahan dan jenis konstruksinya. Ruang, bentuk dan konstruksi dipahami sebagai suatu warisan yang akan mengalami perubahan secara perlahan melalui suatu kebiasaan.

Sehingga, arsitektur vernakular yang identik dengan perkembangan jenis karya arsitektur tanpa arsitek (desainer formal) merupakan istilah atas langkah adaptatif dan antisipatif manusia lokal untuk membuat perlindungan diri dengan lingkungannya secara try and error. Maka, bila cara-cara 
tersebut bisa berlangsung berulang-ulang melalui pola estafet dari generasi ke generasi, vernakular akan menjadi tradisi. Gambar 1 merupakan ilustrasi konsep vernakular dan tradisi hasil analisis penulis.

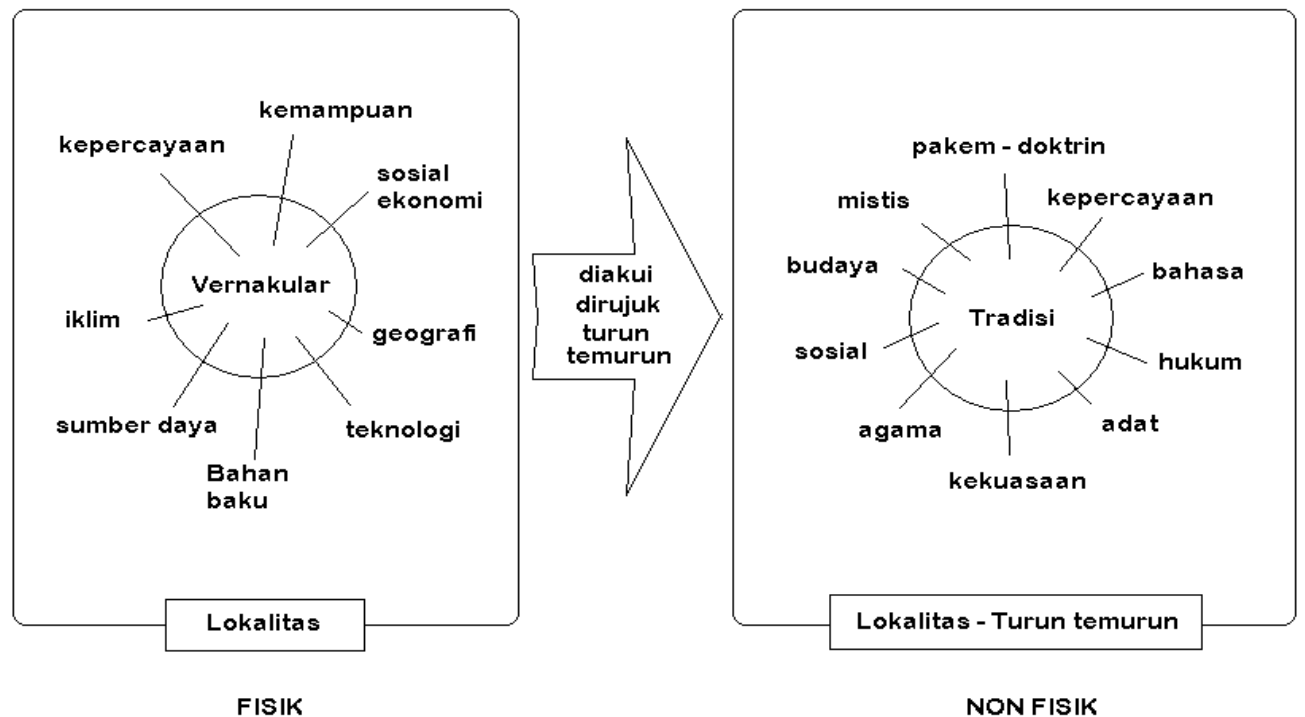

Gambar 1. Ilustrasi konsep vernakular dan tradisi (sumber: analisis penulis).

Berbagai macam aspek yang dapat diidentifikasikan sebagai dasar pertimbangan terbentuknya vernakular yang tertuang dalam Gambar 1 di atas memiliki pengaruh pada arsitektur vernakular yang berbeda-beda tergantung dari lokasi yang berlainan. Perbedaan lokasi ini sangat besar pengaruhnya pada karya desain arsitektur vernakular.

Indonesia adalah salah satu negara yang memiliki banyak ragam arsitektur vernakular. Hampir setiap daerah di Indonesia memiliki arsitektur tradisional yang berbeda-beda. Semuanya memiliki arsitektur yang berciri khas yang berbeda-beda yang dipengaruhi oleh berbagai aspek-aspek yang disebut di atas.

Sejak kemunculan teori teori vernakular, banyak para praktisi yang berusaha untuk melirik bangunan-bangunan vernakular untuk diadaptasikan dengan bangunan karya modernnya. Inilah barangkali yang sekarang kita sebut sebagai gaya vernacular. Untuk itu dalam tulisan ini akan diambil beberapa contoh bangunan vernakular dan juga bangunan dengan gaya vernakular yang kiranya sesuai untuk bisa dilekatkan dengan unsur tradisionalitasnya.

\section{Rumah adat Minangkabau (Rumah Gadang)}

Arsitektur Vernakular yang lekat dengan tradisi Sumatra Barat ini merupakan pengejawantahan dari hasil pembelajaran dan pemahaman masyarakat Minangkabau terhadap alam. Rumah Gadang merupakan perlambang kehadiran satu kaum dalam satu nagari, serta sebagai pusat kehidupan dan kerukunan seperti tempat bermufakat keluarga kaum dan melaksanakan upacara. Bahkan, sebagai tempat merawat anggota keluarga yang sakit. Terbentuknya Rumah Gadang tersebut beserta perkampungannya dipengaruhi oleh berbagai aspek seperti yang mempengaruhi terbentuknya arsitektur vernakular pada umumnya.

Secara fisik, arsitektur Rumah Gadang menunjukkan keselarasan adaptasi terhadap lingkungannya. Atapnya yang lancip merupakan adaptasi terhadap kondisi alam tropis. Dengan atap lancip, niscaya air tidak akan mengendap. Oleh karena itu, walaupun hanya terbuat dari ijuk yang 
berlapis-lapis, Rumah Gadang tidak akan bocor. Demikian juga atap rumah yang membesar ke atas. Tujuannya adalah agar bagian dalam rumah tidak basah karena tempias air hujan yang dibawa angin.
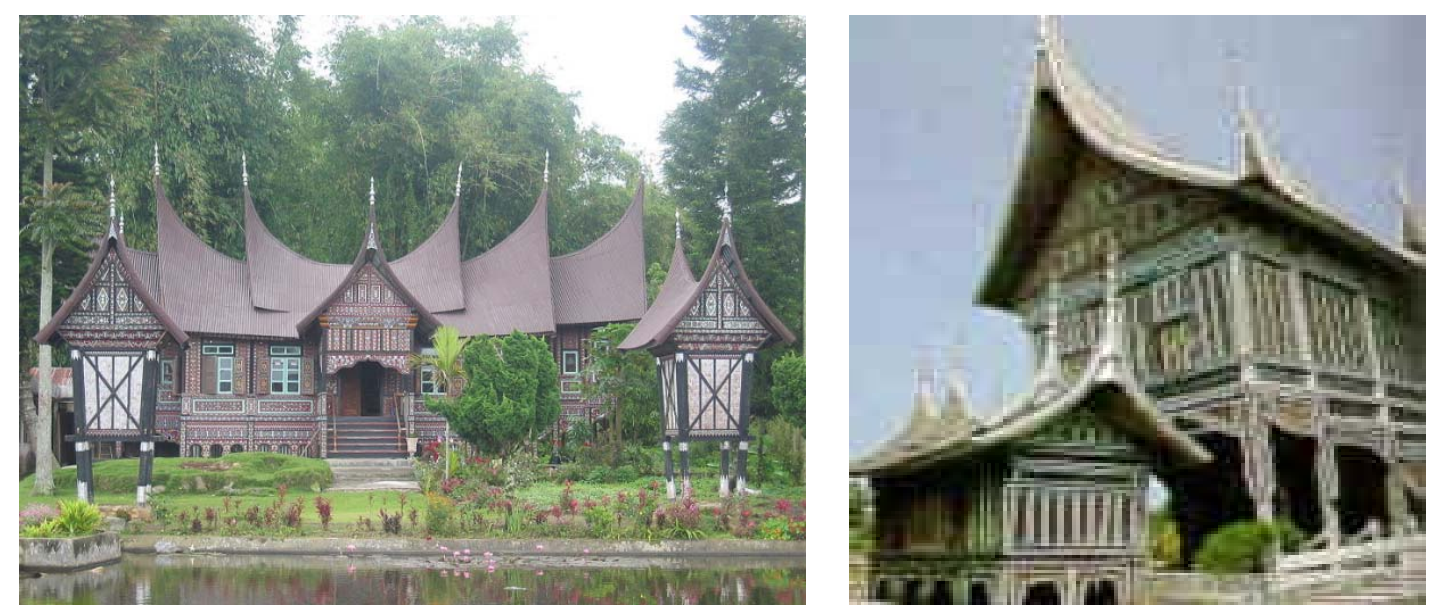

Gambar 2. Rumah Gadang (sumber: Wikipedia)

Bentuk rumah yang berkolong juga tidak semata-mata untuk menghindar dari serangan binatang buas, tetapi juga sebagai bentuk penyikapan pada kondisi alam tropis yang panas. Kolong yang tinggi memungkinkan penghuninya mendapatkan hawa segar. Selain itu, pembangunan Rumah Gadang yang memanjang dari utara ke selatan akan menghindarkan penghuninya dari panas matahari dan hembusan angin secara langsung.

Rumah Gadang merupakan media untuk mewariskan nilai-nilai adat Minangkabau. Melalui Rumah Gadang, tindak-tanduk para kerabat diatur, seperti kesopanan, tata pergaulan, cara makan, dan bagaimana melakukan interaksi dengan anggota kaum ataupun pihak luar. Selain itu, fungsi utama Rumah Gadang adalah sebagai simbol untuk menjaga dan mempertahankan sistem budaya matrilineal - sistem kekerabatan dari garis ibu. Melalui Rumah Gadang inilah, orang-orang Minangkabau menjamin lestarinya sistem matrilineal.

Sama halnya dengan daerah lain di Indonesia, Sumatra Barat juga mengalami heterogenitas kultur yang cukup dominan, sehingga arsitektur vernakularnya pun muncul dalam wujud "campur aduk", berwujud tradisional, namun tak bermakna, karena tidak perduli pada tatanan, hirarki makna, maupun pengertian yang terkandung pada wujud aslinya.

Alhasil, arsitektur vernakular yang ada pada masa lalu yang penuh makna dan filosofi, kini menjadi kisah yang kembali diungkap hanya sebatas bayang-bayang atau pencitraan saja, seperti yang banyak ditemui di hampir di setiap penjuru kota besar di Sumatra Barat. Salah satu contohnya adalah bangunan Balaikota Padang Panjang (Gambar 3).

Namun dibalik semua itu ada sebuah kondisi yang unik yang sampai saat ini masih terjaga kuat yaitu adanya tradisi matrilinear yang kental, sehingga tradisi kaum lelaki yang harus merantau memberikan fenomena tersendiri. Seperti yang kini banyak dijumpai di hampir seluruh kota besar di Indonesia, diyakini bahwa sebagian perantau mengenangnya dengan memberikan citra pada tempat usaha mereka. Contoh yang sering kita jumpai adalah Rumah Makan Padang dengan citra khas bangunannya walaupun hanya sebatas fasade saja (Gambar 4). 


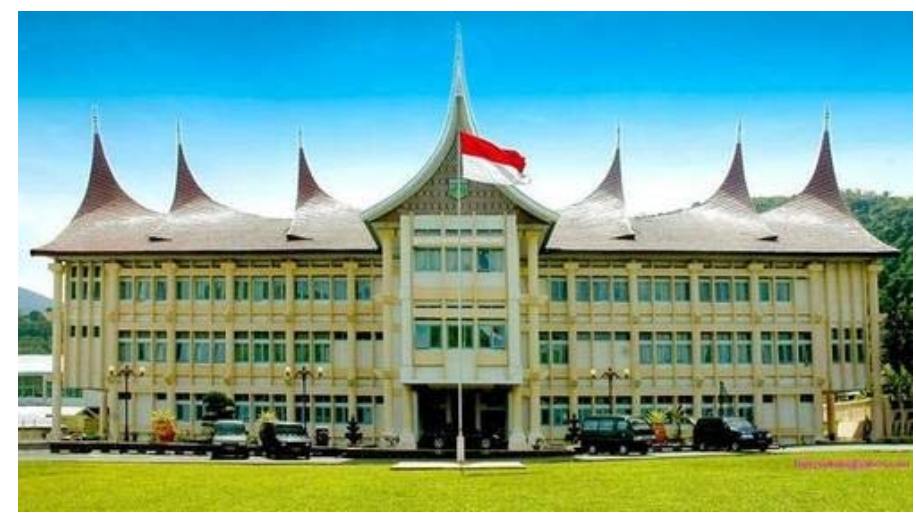

Gambar 3. Balaikota Padang Panjang (sumber: Sulistyo, 2007).
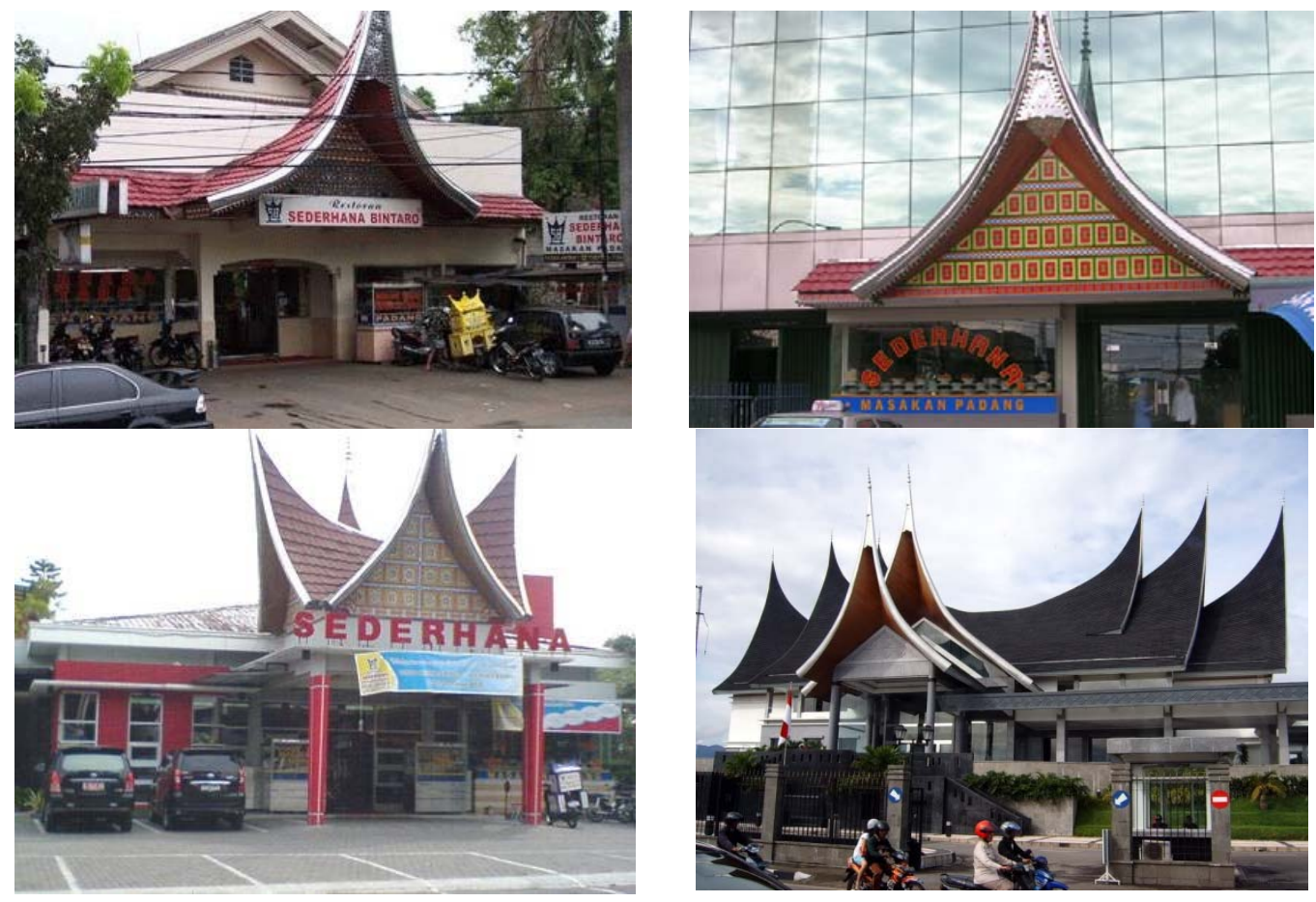

Gambar 4. Gaya vernakular Rumah Makan Padang di sudut-sudut kota (sumber: Google image).

\section{Rumah adat Bali}

Seperti yang sudah diurai diatas, arsitektur vernakular lekat dengan tradisi yang masih hidup, tatanan, wawasan, dan tata laku yang berlaku sehari-hari secara umum. Bali, khususnya daerah pedesaan yang belum banyak mengalami perubahan dari pengaruh external, merupakan saksi atas arsitektur vernakular ini.

Sekedar ilustrasi saja bahwa adat istiadat Bali muncul dari hasil pengejawantahan religi setempat yang memiliki konsep keagungan secara hirarkis. Sehingga konsep ini menjadi salah satu pedoman untuk melakukan atau mengambil keputusan dalam melakukan sesuatu termasuk di antaranya dalam konsepsi mereka membuat zoning kegiatan pada bangunan rumah, yaitu konsep Sanga Mandala (Gambar 5). 


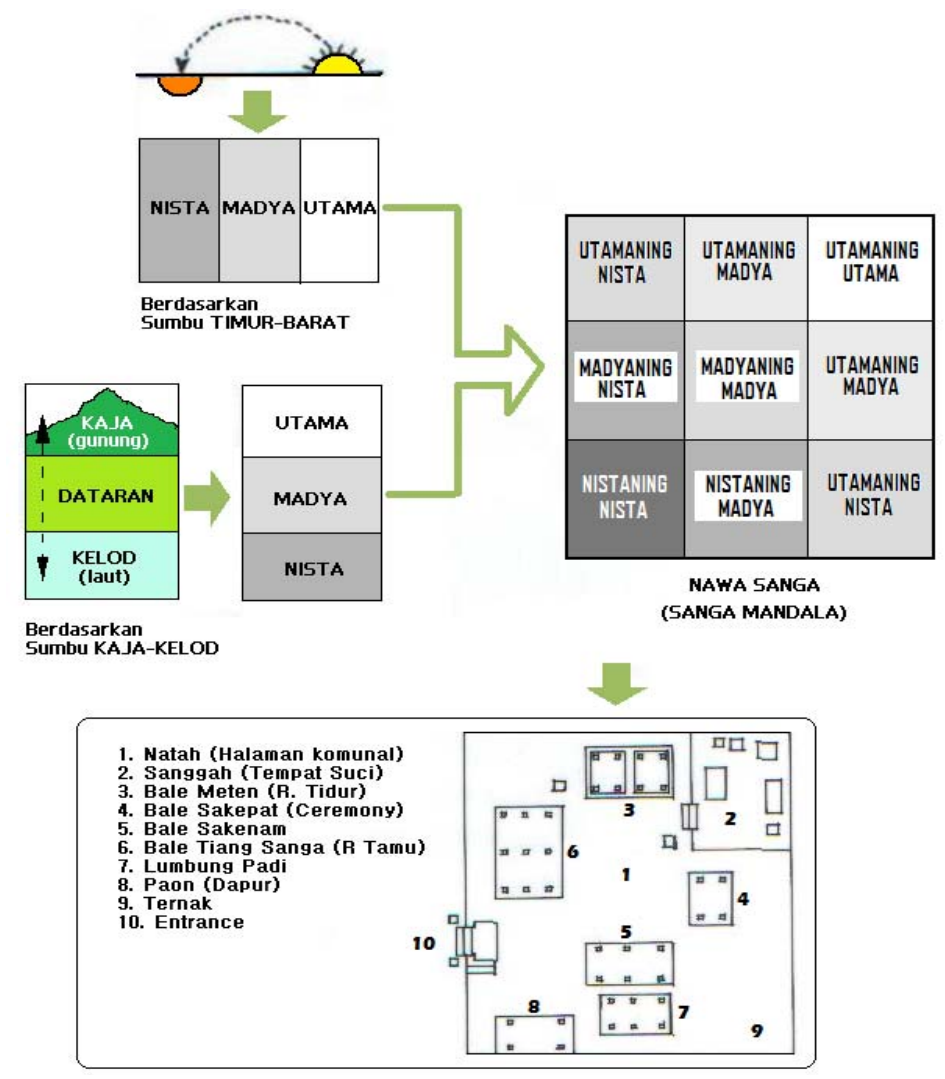

Gambar 5. Konsep Sanga Mandala (sumber: Eko Budiharjo, 1983).

Demikian pula dengan konsep kekuatan bangunan dan ukuran-ukuran yang berdasarkan atas ukuran bagian tubuh manusia-nya (Gambar 6).
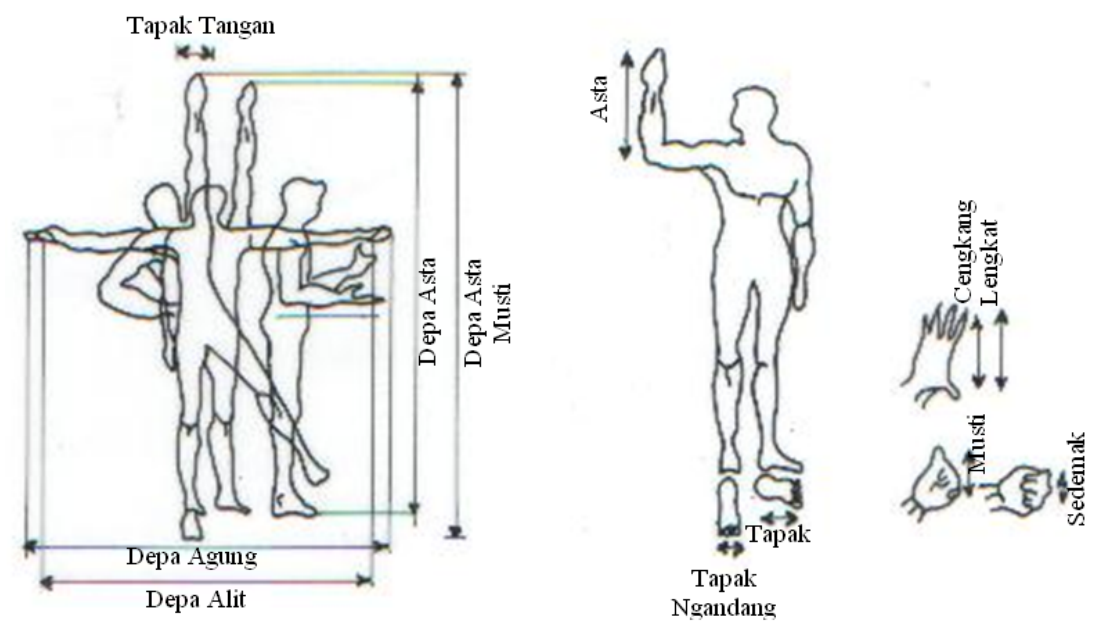

Gambar 3. Ukuran tubuh manusia sebagai dasar pengukuran di Bali (sumber: Adhika, 1994).

Demikianlah konsep yang berakar turun temurun dalam menghasilkan karya arsitektur-nya, filosofi dan makna yang terdapat dalam setiap bentuk, baik ukuran, sudut kemiringan, bahan, ornamen dan jumlah, serta posisi peletakkan tertuang secara mengagumkan dan berhasil menyajikan cita rasa 
bangunan yang jenius. Inilah vernakular asli. Sangat bersahaja, merakyat, sangat beradaptasi dengan lingkungannya, memiliki bahan material setempat yang menonjol seperti batu-bata merah, ijuk, kayu, batu alam dsb, dan mampu bertahan dalam kurun waktu yang lama serta dipercaya turun-temurun (Gambar 6). Pada perkembangan terkini, di mana heterogenitas kultur menjadi dominan, arsitektur vernakular muncul dalam wujud "campur aduk". Berwujud tradisional, tapi tak bermakna, karena tidak perduli pada tatanan, hirarki makna, maupun pengertian yang terkandung pada wujud "asli”-nya. Kondisi ini banyak bermunculan di kota-kota besar di Bali, terutama pada daerah yang berbasis pariwisata. Banyak bisa disaksikan arsitektur yang hanya "bergaya vernakular", seperti pada bangunan dengan tipologi baru yang tidak dikenal secara umum pada tataran tradisional, yaitu pada rancangan hotel, toko, dan sebagainya (Gambar 7 dan 8).
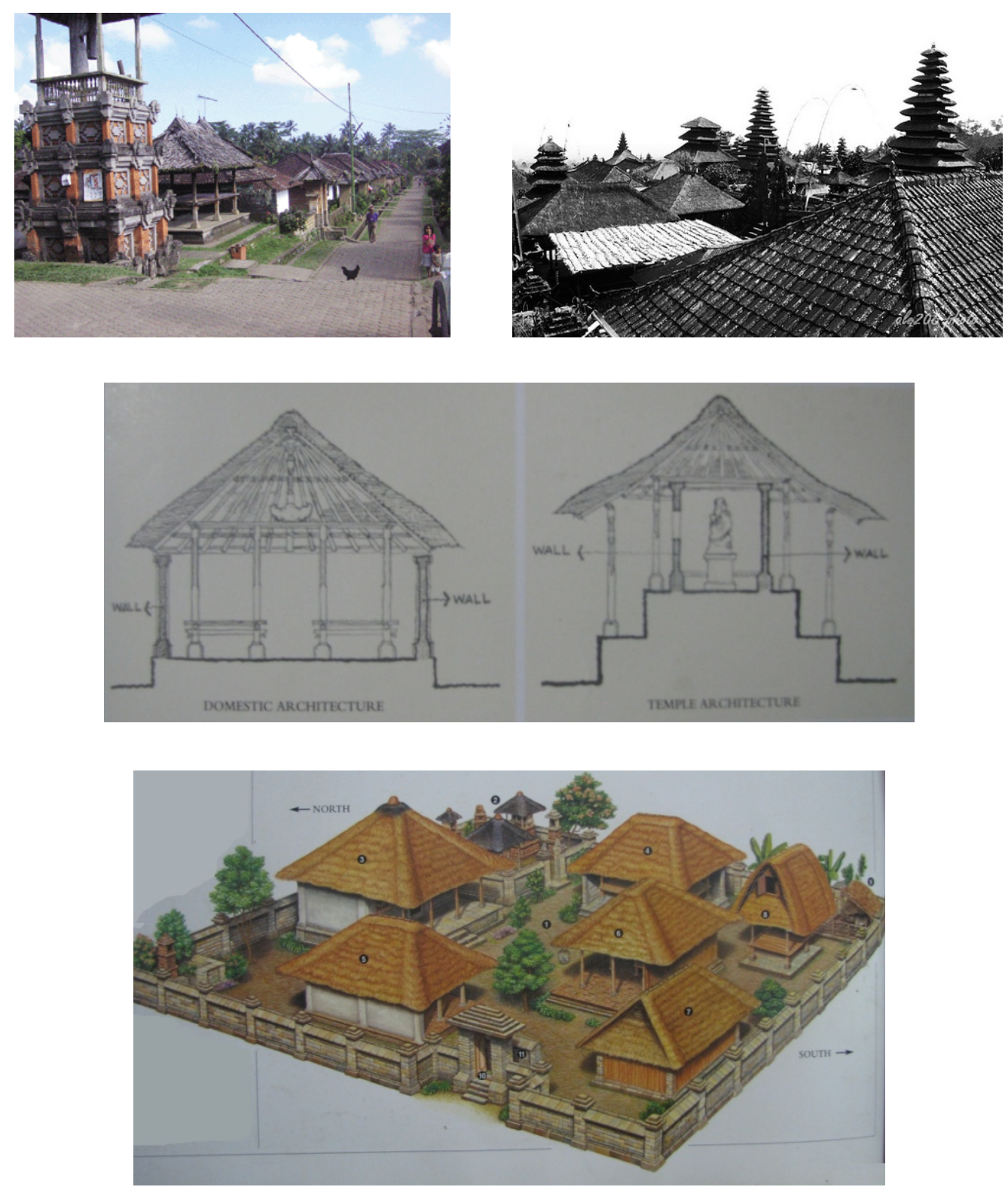

Gambar 6. Bangunan rumah tinggal adat Bali (sumber: Wijaya, 2002 \& Alessio Disalvo, 2009). 


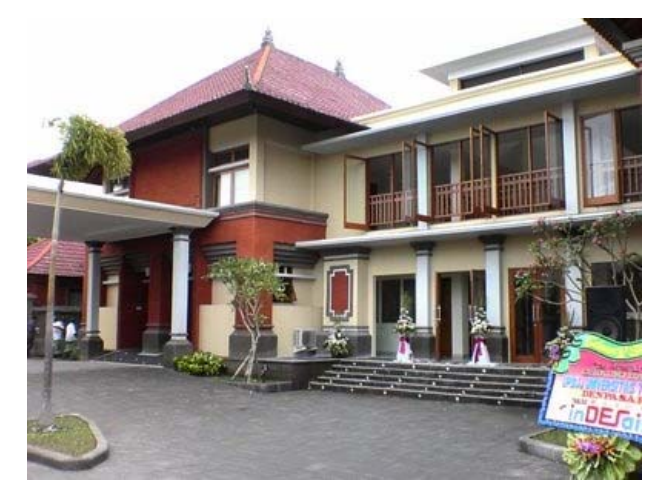

Gambar 7. Ruang Karyawan, Universitas Terbuka di Denpasar (sumber: Arsitektur Bali, 2008).

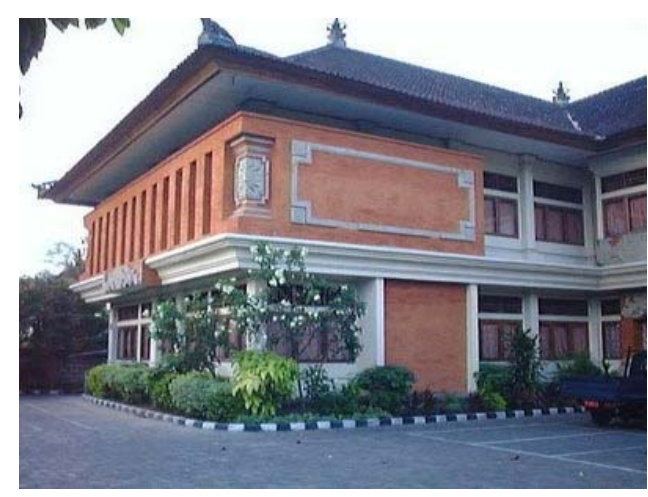

Gambar 8. Kantor Dinas Kesehatan Kodya Denpasar (sumber: Arsitektur Bali, 2008).

Jadi, arsitektur bergaya vernakular adalah merupakan transformasi dari situasi kultur homogen ke situasi yang lebih heterogen dan berusaha sebisa mungkin untuk menghadirkan kembali citra, bayang-bayang realitas arsitektur asli vernakuler.

\section{PENUTUP}

Arsitektur Vernakular adalah istilah yang digunakan untuk mengkatagorikan metode kontruksi yang menggunakan sumber daya orisinal lokal untuk memenuhi kebutuhan lokal. Arsitektur vernakular berkembang setiap waktu untuk merefleksikan lingkungan, budaya, dan sejarah dari daerah dimana karya arsitektur tersebut muncul dan berada atau eksis.

Berlawanan dengan arsitektur yang dirancang oleh seorang arsitek yang lahir melalui proses pendidikan formal, pengetahuan mengenai bangunan pada arsitektur vernakular hanyalah muncul dari sang perancang otodidak yang diperoleh dan disalurkan melalui tradisi lokal semata dan biasanya berdasarkan trial and error (intuisi) yang diturunkan dari generasi ke generasi.

Struktur bangunan vernakular mudah dipelajari dan dimengerti; terbuat dari material local; cocok secara ekologi, yaitu sesuai dengan iklim lokal, flora, fauna dan pola kehidupan. Dengan demikian, bangunan vernakular memiliki kesesuaian dengan lingkungan setempat dan memiliki skala manusia atau skala rakyat biasa, bukan skala keagungan istana kerajaan ataupun skala bangunan keagamaan yang megah.

Proses membangunnya lebih penting daripada hasil akhir produknya. Kombinasi dari ketepatan yang baik secara ekologi, skala manusia, kualitas, bersamaan dengan perhatian yang kuat untuk dekorasi, ornamentasi dan penghiasan, membawa kepada sensasi kesederhanaan yang menghasilkan kemewahan yang sesungguhnya.

Arsitektur vernakular bisa dikatakan sebagai arsitektur rakyat, maka ketika kita membicarakan soal arsitektur vernakular, yang kita bicarakan di sini bukanlah hanya sekedar bangunan, tapi juga meliputi segala macam falsafah yang menyertainya dimana hal itu merupakan dasar segala macam pertimbangan kejeniusan masyarakat.

Kemudian apabila seluruh konsepsi dan hasil karya tersebut diakui secara aklamasi dan hasilnya sangat teruji dalam kurun waktu yang relatif panjang dan sangat lama hingga mendarah daging, karya vernakular ini masuk dalam klasifikasi karya arsitektur tradisional. 


\section{DAFTAR PUSTAKA}

Arsitekur Bali. (2008). Gedung Milik Pemerintah. Diakses dari http://arsitekbali.blogspot.com/2008_12 01_archive.html.

Arsitekur Bali. (2008). Universitas Terbuka di Denpasar. Diakses dari http://arsitekbali.blogspot.com/2008/12/universitas-terbuka-di-denpasar.html.

Budiharjo, Eko. (1983). Menuju Arsitektur Indonesia. Bandung: Alumni.

Disalvo, Alessio. (2009). Alessio Disalvo's Photostream. Diakses dari http://www.flickr.com/photos/alessiodisalvo/4130062711/in/photostream/.

Rudofsky, Bernard. (1964). Architecture without Architects. New York: Museum of Modern Art.

Salura, Purnama. (2008). Arsitektur Venakular - Mahluk Apa Itu? Diakses dari http://vernacular.edu2000.org/content/view/358/388/.

Sulistio, Harry. (2007). Balaikota Padang Panjang. Diakses dari http://www.panoramio.com/photo/4415061.

Sumalyo, Yulianto. (1993). Arsitektur Kolonial Belanda di Indonesia. Yogyakarta: Gadjah Mada University Press. 